\title{
The Form and the Function that Defines and Associates Definite and Indefinite Articles in English Grammar
}

\author{
Dennis Michael Bryant (Corresponding author) \\ University of Canberra \\ Kirinari Street, Bruce, Canberra, Australian Capital Territory, Australia
}

Tel: 61-400-499-265Ｅ-mail: DrDennisBryant@gmail.com

Received: March 23, 2020 Accepted: May 9, 2020 Published: June 19, 2020

doi:10.5296/ijch.v7i1.17213 URL: https://doi.org/10.5296/ijch.v7i1.17213

\begin{abstract}
Teachers expect that grammatical metadata is evidence-based, and not subject to inclusion of poetic licence as is evident in Twain's 'The Prince and the Pauper' novel, in which two characters are found to be identical in form (being thitherto unrecognised identically shaped twins) as well as being alike in function (they both manage to pass as royal princes in-waiting). But it must be asked, could similar poetic licence have inadvertently found its way into the grammatical treatment of Articles? This question must be asked because past grammars have not used an evidence-based approach to describing Articles. To address this shortcoming, and believing that an analytical re-measurement is not out of place, this paper is confidant in proposing a substantial treatment of articles, which is based on kindred form and kindred function and not poetic licence. The methodology of this paper, which is to employ discerning exemplars of English sentences, emulates three recent publications, the first of which concerned altering word prominence in pursuit of grammatical convenience; while the remaining papers were concerned with ESL mastery of the verb complex; and lastly, the decoding of contractions. Given that some ESL learners have never required (nor acquired) Articles in order to attain first language competency (say, for example, Czech and some Baltic languages), this paper will serve to shed new light on the hidden-in-plain-sight operations of English, and could become a source document for today's ESL teachers on the treatment of Articles.
\end{abstract}

Keywords: ESL educational practice, ESL curriculum redevelopment, ESL teaching, Second 
language acquisition

\section{Introduction}

Believing that a Transformationalist (Chomsky, 1965, 1957) view of grammar was poised to become an accepted successor to previous systems, such as Structuralism (Fries, 1952), as well as earlier Traditional grammars (Jespersen, 1948), Gunn \& Eagleson (1966) defined articles as 'structural words' (p. 65), based on their interpretation that such words have no lexical content but operate only to perform a grammatical function. To accept such a definition would be dangerous because it is a generalisation that has not been shown to be true. Mitchell (1995, p. 39), to the contrary, notes that Old English used 'one' as the Indefinite article — as did Middle English (Cook, 1961) — which clearly indicates a lexical meaning of singular entity. Apart from spelling differences between those past times and now, the Indefinite article can be seen in Mitchell's example of 'an wulf wearth asend' (1995, p. 39), which he translates as 'one wolf / a wolf was sent'. The example shows that an Indefinite article indeed has a lexical meaning of singularity, in the same manner as does a randomly chosen adjective, such as 'red'. In short, Mitchell's example contradicts the overly generalised conclusion given by Gunn \& Eagleson (1966), and described above, that the Indefinite article cannot be seen to be operating in a lexical role.

An interesting twist to note here is that today's Modern English has reduced the Indefinite article ('an') to its simplest usage ('a') in most usage, but that reduction is over-ruled and the original full article reappears with its nasal (n) attachment before a word that is deemed to begin with a vowel sound. Taking this twist a step further, 'one' is maintained as an adjective not just in the numbering sequence but is used, for example, as a pronominal in an expression like 'One never knows'. To be more specific, 'one' may well be described as a 'demonstrative' pronoun by function. While 'one' is not customarily categorised within the demonstrative grouping, a 'demonstrative' pronoun conclusion would be supported by Sapir (1921, p. 108).

Bolinger, as an adherent of the term morpheme, refers to articles as either 'system morphemes' or alternatively as 'function words' (1968, pp. 59-62). However, in spite of bringing no advance in clarity, he does makes a contribution to the literature on articles by providing a description of the vocalic form of articles when outlining the three pronunciations of the Definite article, and the four pronunciations of the Indefinite article (pp. 59-62).

Although it might be an expectation that, over time, the literature would explain the roles and descriptions of articles in a more circumspect light by evincing clear definitions, the continued absence of such a step forward can only be lamented. As part of the arrival of 'new approaches to grammar' heralded by Gunn \& Eagleson (1966, p. 119), a new piece of nomenclature for articles was added by Langacker (1973), who preferred the term 'grammatical morpheme' for articles. In spite of having a new term, it would be unwise to assume that there was a satisfactory accompanying description, which could discriminate between morphemes that function grammatically and morphemes that carry lexical content. Langacker, in fact notes that such a distinction would be 'correct up to a point, but it [the distinction] should not be pushed too far' (p. 76). It might be asked whether ESL (English as 
a Second Language) teachers have been any better off for that supposed definition because it sheds scant knowledge, neither elucidating form nor function, as far as articles are concerned?

Based on reviewing the literature, this paper holds that previous English grammars have failed to identify a theme upon which comparisons can be made of Definite articles (Definites) when compared to Indefinite articles (Indefinites). Furthermore, this failure can be taken to indicate misdirection in yesteryears' grammatical classifications, perhaps towards past indulgence in poetic licence rather than facts. Whatever the cause of misdirection, it is one that needs to be addressed adequately, and with some despatch. The new discernments made in this paper's revision of English articles should be congruous with assisting student learning autonomy, as espoused by Benson (2001), especially given that this fresh approach aims to link concepts together. Having made this claim, there is no intended criticism of the range and depth of help provided by some earlier explications. See, for example, the efforts of Christison (2002), Cohen (1998), Dornyei (2001), Swick (2009), and Torres-Gouzerh (2019).

Therefore, this paper proposes as necessary an evidence-based analysis to be undertaken, following a suggested theme of congruence in the form and function of articles. If this paper demonstrates that degrees of congruence do exist, it could almost become inevitable that definitions for other parts of speech are similarly out-of-date, and may have been in that state for some time. While the amount of exposure that native speakers experience in their first language development always leads to mastery, the same proposition is not always true for ESL learners. Therein is a justification for reviewing briefly, the past history of article classification with an intention of correctly describing the form and function of articles in English.

There has been a tendency in current times (see, for example, Larsen-Freeman \& Celce-Murcia (2016); Gass (2013); Saville-Troike (2012)), as well as in past times (typified by, say, Bolinger (1968)), to claim that Definites include just a single member ('the'). However, putting aside this historical blindspot, this paper proposes that Definites should include multiple members, all of whom display strong congruence of form. They are 'the', 'this', 'that', 'these', 'those', 'their' and 'theirs'. The congruence in form of these Definites is obvious in their spelling. They all begin with the same written digraph ('th)', which is voiced as a fricative consonant (O'Connor, 1973; Abercrombie, 1967). A second point to note is that the two plural Definites ('these, those') are both pronounced with a sibilant final 's' sound, making evident their congruence of form to each other, and to one other member; namely, 'this'. This similarity is hidden by the spelling system, but is evident in an International Phonetic Alphabet spelling. For example, 'these' would be written in IPA as 'ðiz' which shows a voiced final sibilant. If there is a slightly less congruous form within Definites, it is 'the'. The latter form, in lacking a final letter, could perhaps indicate that it was the root from which the others evolved, in days of Old English development or earlier. Additionally, it could be seen as perhaps a harbinger of difference in function.

The congruence in Definites' function would be immediately recognisable by native speakers due to the fact that the bulk of them represent grammatical number, because 'this' and 'that' are perceived as singular; whereas the remaining 'these' and 'those' indicate plurality. 
Operating in a different membership paradigm and indicating perceived distance from a speaker, 'this' and 'these' are interpreted as close in distance; whereas the remaining 'that' and 'those' indicate being further apart in distance. By contrast, 'the' functions differently; namely as a carrier of discourse inference. As can be seen, Definites take a very limited number of forms. In fact, linguists would classify Definites as a 'closed class' (Bolinger, 1968 , p. 55), which means that no new members are believed to be possible.

By contrast, a quick glance at English lexicon would indicate that Indefinites take a large number of forms, and are much more diverse than the already discussed Definites. In fact, linguists classify Indefinites as an 'open class' (Bolinger, 1968, p. 55), which means that new members may appear and take up an Indefinite role. Given large numbers, it may not be surprising to find a lack of congruence in Indefinites form. However, limited grouping of Indefinites is indeed possible because they take form as either as a single word, or else as a short combination of words. As an aside on the occurrence rate of Definites and Indefinites in other languages, but perhaps of relevance to some teachers, Gass (2013, p. 96), quoting from Duskova (1983), notes that 'Czech [is a] language that does not have definite or indefinite articles'.

In reaching the end of the literature review, one final point is obvious by its unexpected absence in the literature; namely, prominence (which might be defined as distinctiveness). The question that arises is: do the two types of article exhibit equal or unequal prominence? This paper accepts that both articles may exhibit a degree of prominence but that the prominence of Indefinites can in no way rival the prominence of Definites. This conclusion may be reached by observing that Definites (redefined above as having not one, but five members) exhibit a tight and consistent coherence in form; are mostly coherent in function; are a closed set which can convey a sense of uniqueness; as well as being very small in membership numbers, thus implying a private club image.

\section{Methodology}

This paper's approach to locating and describing English articles is done through an organized presentation, and discussion, of exemplar sentences, each of which demonstrates the nature of English articles. Presentations are organized into sections which deal firstly with the form and function of Definites and Indefinites, and concluding with a short treatment that discusses cases of the juxtapositioning usage of Definites and Indefinites. This order in first presenting Definites has been chosen for the reason that it is an accepted norm in pedagogy to begin with what is termed as a 'known' (whether this be an Definite experience, or topic) and move towards an 'unknown' (therefore less Definite) topic or experience.

This paper's approach of analytical re-measurement is not out of place, because it emulates the approach taken in recently published papers, these being the innovative focus-promotion premise which concerned altering word prominence in pursuit of grammatical convenience (Bryant, 2019a); in focussing on verb structure mastery for ESL speakers (Bryant, 2019b); and, in focusing on decoding contractions, again for ESL speakers (Bryant, 2019c). The said publications have shed new light on the hidden-in-plain-sight features and operations of English, and hopefully this paper will serve to inform ESL teachers, similarly. This paper 


\section{Macrothink}

may also function as a helpful foil to publications which aim to provide detailed lists of common pitfalls in English (see, for example, Karjalainen (2012)).

\section{Findings}

The following sections comprise of a number of exemplar samples, whose purpose is to demonstrate the form and function of English Definites. Among other things, the findings below should impress upon readers the non-truth of Articles being simple; subtle, yes but simple, no.

\subsection{The Form of Definites}

There are six Definite articles, but seven if the count includes the inflected form 'theirs'. Their close familiarity of form is shown in the exemplar below.

This (ðIs) book; these (ðiz) letters; those people; that koala; the bushfires; their game; it's theirs.

The exemplars are similar in form in that they all begin with a dental fricative consonant 'th' (O'Connor, p. 61), which is then followed by a vowel, although the vowel does vary in form. Speaking in terms of English spelling conventions, three articles end in a sibilant alveolar fricative consonant ' $\mathrm{s}$ ' ('this, these, those, theirs'); one ends in a alveolar stop consonant ' $\mathrm{t}$ ' ('that'); one ends in ' $r$ ' ('their'); and one ('the') has no final consonant, perhaps because it was once the original model that was likely extended by inflection. To some extent, English spelling conventions obscure this similarity in form and to hint at this situation, the IPA form has been shown, for the first two exemplars. Although voiced (and its curiously named co-term voiceless) are not mentioned above, the IPA ' $\mathrm{z}$ ' is equivalent to ' $\mathrm{s}$ ' except that it has a greater degree of force in its voicing, being thus described as voiced.

\subsection{The Functioning of Definites}

A majority ('this, that, these, those, their, theirs') of Definites may best be described as serving in one or more grammatical capacities; while the remaining Definite ('the') may be described as serving in one or more discourse capacities, and examples are given below.

\subsection{Grammatical Definite Exemplars}

Grammatical Definites serve to indicate number (singularity, or plurality) as well as distance (close, or more distant), which is actual or perceived, and finally 'ownership'.

This key shouldn't be here. You will need these keys.

That teacher is exceptional, but those teachers have continually succeeded in educating ghetto students.

Their teammates are excellent, but when it comes to opposition sides, theirs are formidable. 
Due to ellipsis (which might briefly described as the elevation of a Definite to a pronominal state, which is due to the concomitant deletion of its nominal partner), grammatical Definites can thus serve in a role of demonstrative pronoun, as shown in the exemplar below.

You can ride any horse, but not that one. It's too wild. This one is OK.

\subsection{Discourse Definite Exemplars}

Turning now to the discourse functionality of the remaining Definite, 'the' serves to carry to a listener, or a reader, an inference concerning recognition, which has two forms, these being either assumed prior recognition; or provided post identification. These two variations on recognition are exemplified and discussed next.

As curious as it is, I met the French Prime Minister near the Eiffel Tower.

In the exemplar above, by prefacing each nominal phrase with 'the', the speaker is insinuating that the listener is likely to be familiar with both the minister and the tower; that is, it conveys the idea that the listener has prior recognition of both the person and the place. This is not to say that the listener would necessarily know the name of the minister, but instead would be aware of the existence of 'minister' as a political structure. The same can be said for the listener's knowledge of the existence of a famous tower, symbolic of France.

Are you talking about Elvis, thé King?

The second discourse function concerns adding stress to the Definite article, and this emphatic definiteness helps to indicate a special status. In the exemplar above, if 'the' were to be given a strong voicing and hence greater prominence, it would indicate that the speaker is implying that Elvis is unique. Rephrased, the utterance would carry an inference that Elvis is the one and only King.

The racehorses, that you are about to see, have all been retired to pasture. The remaining horse will be sold, soon.

Apart from assumed prior recognition, provided post identification is an option and this is exemplified above. In a post identification circumstance, 'the' (and its nominal partner) precedes a relative clause which contains information on a topic; here, racehorses. A second point to note is that 'the' can accompany a singular, or as shown above, a plural noun.

Two of the horses, that we agist on this property, have a penchant for jumping the fences and racing to greater freedom in the surrounding national park.

The exemplar above differs from earlier exemplars in that it features a partitive construction that introduces 'the' which again precedes a post identification clause.

I hate them boys! Them's too coarse for my liking!

Taking a devil's advocate approach, if there were to be a new member in Definites, it might be as shown in the exemplar above. However, acceptance would be a struggle because over the years, there have been many instances of prescription-ism and proscription-ism as regards which linguistic forms should be acceptable or rejected in English. As an early example of 


\section{Macrothink}

controlling language usage, the Royal Society sought 'a practical scheme for informing popular taste on sound principles', as quoted by Potter (1966, p. 120).

Moving onto English Indefinites, the following sections comprise of a number of exemplar samples, whose purpose is to demonstrate Indefinites form and function.

\subsection{The Form of Indefinites}

A, A few of, A lot of,

Several, Some,

None of.

Indefinites take a large number of forms and, as an open class, can accept new members. However, limited grouping of Indefinites is possible because they exist either as a single word, or else as a short grouping of words.

\subsection{The Functioning of Indefinite Exemplars}

An explication addressing the congruency of single and grouped words now follows.

'A' indicates one instance.

'A couple of' indicates two instances.

'A few' indicates two or three instances.

'Some' indicates more than a few but otherwise an unspecified number.

'Several' indicates less than many but probably not a majority.

'Many' indicates a large number and possibly a majority.

Sometimes, a group can be empty; that is, the group has no members. 'None', and its longer but more emphatic and prominent form of 'Not one', both indicate a group with no members; that is, an absence of presence.

None of the players is here yet.

All of the players are not here yet.

Mitchel (1954, p. 185), in his 1962 ninth reprint, observes that 'Though in its form none is the negative of one, in its meaning it appears to be the negative of all', making the two exemplars above equivalent in terms of meaning. However, in terms of groups, the negator 'not' decimates the complete membership proposed earlier in the utterance as 'All' (as shown in the above exemplar).

\subsection{Juxtaposing Definites and Indefinites}

Throughout this paper, there has been a separation of discussion on Definites and Indefinites. A possible yet unintended consequence that may arise due to this separation is the take-up of 
an assumption that the two types must operate independently. This section will counter that misconception.

'I'll have the one with the star', said the shopper.

When selecting a cake, can one be too careful? Clearly, the display case has only a single, starred cake. The shopper adds emphatic definiteness to her request by twice using 'the'.

'I'll have the ones with the star, please'.

In the exemplar above, the shopper notices that there are more than one cake with a star, and proceeds to acquire all of the starred cakes. She indicates this through the pluralised 'ones'. Emphatic definiteness is again used.

'I want four cakes. I'll have ones with a star'.

For all intents and purposes, the exemplar above is synonymous with the prior exemplar in meaning, but it excludes emphatic definiteness due to the exclusion of 'the'. In fact, 'ones' is functioning in a discourse manner as a demonstrative pronoun (an adjective which changes classes due to ellipsis of its noun), representing 'four cakes' from the first part of the utterance.

'It was quite a search to find a Corona-virus mask'.

'It was quite the search to find a Corona-virus mask'.

Of the two exemplars above, the first is the ordinary form that would be used by speakers in most instances; whereas the second becomes prominent due to the replacement of ' $a$ ' with 'the'. This utterance was spoken in New York by a frantic lady who struggled but eventually found a shop where not all the Corona-virus masks had been sold out.

'Not this one; and not these ones, either; and definitely not those'.

The final exemplar, above, shows a mix of Articles. The Definites are operating adjectivally ('this one') and in a demonstrative pronoun role ('not those'); while the Indefinites can be seen as operating in a demonstrative pronoun role ('these ones').

\section{Limitation}

This paper provided a modest set of exemplars, in the belief that most readers would have sufficient fluency in English to generalise the provided exemplars to reflect other circumstances, correctly.

\section{Conclusion}

In respect of grammatical metadata on articles, this paper questioned whether past literature has been evidence-based, or has succumbed to poetic licence as is found in Twain's 'The Prince and the Pauper' novel, in which two characters are found to be identical in form (identical twins) as well as alike in function (both passing as royal princes in-waiting). A perusal of the literature found scant evidence-based treatment of articles, notwithstanding whether that treatment was in examples or in grammatical definitions. Introducing a theme of 
comparisons based on analyses of form and function as guidelines, and approaching the task using a methodology which presented exemplar sentences that demonstrate English usage, it was possible for this paper to provide a framework to discuss and appreciate English articles, both Definites and Indefinites, thereby leaving behind poetic licence and preconceived notions. This paper's approach of analytical re-measurement is not out of place, because it emulates the approach taken in recently published papers, which treated the innovative focus-promotion premise as it detailed the process of altering word prominence in pursuit of grammatical convenience; and also in a second paper which describes verb structures to assist ESL speaker mastery; and, in a third paper that focused on decoding contractions, which are semaphores that need to be interpreted by ESL speakers. The said publications have shed new light on the hidden-in-plain-sight features and operations of English, and hopefully this paper will serve to inform ESL teachers, similarly. Given that some ESL learners have never required articles in order to attain first language competency (say, for example as a starting point, Czech; but not forgetting that other ESL learners may have struggled with incorporating article usage into their idiolect), it is hoped that current ESL teachers may now be more confident in their students' success, based on this paper's grammatical refinement of articles.

\section{References}

Abercrombie, D. (1967). Elements of General Phonetics. Edinburgh: Edinburgh University Press.

Benson, P. (2001). Teaching and researching autonomy in language learning. New York: Longman.

Bolinger, D. (1968). Aspects of Language. New York: Harcourt, Brace \& World, Inc.

Bryant, D. M. (2019a). Focussing on Promotion in English Sentences to inform ESL Educational Practice. Language, Literature and Culture, 2(3), 108-113. [Online] Available: http://www.aascit.org/journal/archive?journalId=932

Bryant, D. M. (2019b). Focussing on Building up ESL Perception of Verb Slot Complexity to inform Educational Practice. Language, Literature and Culture, 2(3), 133-138. [Online] Available: http://www.aascit.org/journal/archive?journalId=932

Bryant, D. M. (2019c). Focussing on Decoding Contractions in English Sentences to Inform ESL Educational Practice. International Journal of Culture and History, 6(2), 90-101. https://doi.org/10.5296/ijch.v6i2

Chomsky, N. (1957). Syntactic structures. Mouton: The Hague. https://doi.org/10.1515/9783112316009

Chomsky, N. (1965). Aspects of the theory of syntax. New York: Harper \& Row. https://doi.org/10.21236/AD0616323

Christison, M. A. (2002). Multiple intelligences and language learning: A guidebook of theory, activities, inventories, and resources. Burlingame, CA: Alta Book Center. ISBN: 
$1-882483-75-3$.

Cohen, A. D. (1998). Strategies in learning and using a second language. New York: Longman.

Cook, D. (1961). The Canterbury Tales of Geoffrey Chaucer. New York: Anchor Books.

Dornyei, Z. (2001). Teaching and researching motivation. New York: Longman. https://doi.org/10.1075/hop.5.mot1

Duskova, L. (1983). On sources of errors in foreign language learning. In B. Robinett, \& J. Schachter (Eds.), Second Language Learning: Contrastive Analysis (pp. 215-233). Ann Arbor, Michigan: University of Michigan Press.

Fries, C. C. (1952). The Structure of English. New York: Harcourt, Brace and World.

Gass, S. (2013). Second Language Aquisition: An Introductory Course. (4th ed.). New York: Routledge. https://doi.org/10.4324/9780203137093

Gunn, J. S., \& Eagleson, R. D. (1966). Survey of Language. Sydney: Angus \& Robertson.

Jespersen, J. O. (1948). Essentials of English Grammar. London: Allen \& Unwin.

Karjalainen, J. (2012). The Joy of English: 100 Illuminating Conversations. London: Little Brown Book Group.

Langacker, R. W. (1973). Language and its Structure: some fundamental linguistic concepts. (2nd ed.). New York: Harcourt Brace Jovanovic, Inc.

Larsen-Freeman, D., \& Celce-Murcia, M. (2016). The Grammar Book: Form, Meaning and Use for English Language Teachers. (3rd ed.). Boston, Massachusetts: Cengage Learning.

Mitchell, A. G. (1962). The Use of English. Sydney: Angus \& Robertson.

Mitchell, B. (1995). An Invitation to Old English and Anglo-Saxon England. Oxford: Blackwell Publishers Ltd.

O'Connor, J. D. (1973). Phonetics. Language \& Linguistics. Harmondsworth, England: Penguin Books.

Potter, S. (1966). Our Language. (2nd ed.). Harmondsworth, Middlesex: Penguin Books.

Sapir, E. (1921). Language: An Introduction to the Study of Speech. New York: Harcourt, Brace \& World, Inc.

Seville-Troike, M. (2012). Introducing Second Language Acquisition. (2nd ed.). Cambridge: Cambridge University Press. https://doi.org/10.1017/CBO9780511888830

Swick, E. (2009). Verbs and Essentials of Grammar for ESL Learners. New York: McGraw-Hill.

Torres-Gouzerh, R. (2019). Practice Makes Perfect: Intermediate English Grammar. (3rd ed.). New York: McGraw-Hill Education. 


\section{Macrothink}

ISSN 2332-5518

\section{Copyright Disclaimer}

Copyright reserved by the author(s).

This article is an open-access article distributed under the terms and conditions of the Creative Commons Attribution license (http://creativecommons.org/licenses/by/3.0/). 